\title{
G.M. Starukh
}

\section{STUDY OF TETRACYCLINE ADSORPTION BY Zn-Al MIXED OXIDES AND LAYERED DOUBLE HYDROXIDES}

\author{
Chuiko Institute of Surface Chemistry of National Academy of Sciences of Ukraine \\ 17 General Naumov Str., Kyiv, 03164,_Ukraine, E-mail: starukh_galina@ukr.net
}

The adsorption of tetracycline (TC) from aqueous solutions onto Zn-Al mixed oxides has been studied by batch experiment. A partial conversion of mixed oxides into the layered double hydroxides $(L D H)$ has been revealed simultaneously with TC adsorption. The ligand-promoted dissolution is occurring during $T C$ adsorption by mixed oxides. It has been found that TC:Al ${ }^{3+}$ complexes with ratio 2:1 and 1:1 have been formed in solution after contact of TC with mixed oxides. Zn-Al LDHs were prepared by coprecipitation method and were used for comparative study of TC adsorption from aqueous solutions. $\mathrm{Zn}$-Al mixed oxides have a higher TC adsorption capacity in comparison with that of Zn-Al LDH. The experimental results were analyzed within mathematical models for equilibrium sorption on solid surfaces.

Keywords: layered double hydroxides, Zn-Al mixed oxides, reconstruction, tetracycline, adsorption, complexation

\section{INTRODUCTION}

Pharmaceutical antibiotics have been applied worldwide in human therapy and the farming industry. Thus, antibiotics (especially tetracycline antibiotics) have attracted many people's attention recently. Tetracycline (TC) has been considered to be a class of potential pollutants [1]. Most TC antibiotics enter the environment through municipal effluent, sewage sludge, solid wastes and manure applications. The continuous release of TC into aquatic environment increases the potential for antibiotic resistance among microbial populations and the degradation by-products have been proven even more toxic than the parents [2]. Therefore, it is urgent to develop efficient and economical technologies to remove TC. There are many technologies available for TC removal including adsorption, oxidation, and photochemical degradation [3]. The adsorption process is a practical method for the in situ removal of TC from wastewater.

As cost-competitive sorbents, layered double hydroxides (LDH) have been found capable of immobilizing a variety of aqueous inorganic and organic anions [4]. LDHs are anionic clays composed of positively charged layers of general formula $\left[\mathrm{M}^{3+}{ }_{\mathrm{x}} \mathrm{M}^{2+}{ }_{\mathrm{y}} \mathrm{O}_{\mathrm{m}}(\mathrm{OH})_{\mathrm{n}}\right]^{(3 \mathrm{x}+2 \mathrm{y}-2 \mathrm{~m}-\mathrm{n})+}$ and interlayer inorganic or organic anions compensating the positive charge as well as hydrate water molecules
[5]. The large variety of compositions can be developed by altering the nature of the divalent $\left(\mathrm{Mg}^{2+}, \mathrm{Zn}^{2+}, \mathrm{Fe}^{2+}, \mathrm{Co}^{2+}, \mathrm{Ni}^{2+}, \mathrm{Cu}^{2+}\right.$, etc. $)$ and trivalent $\left(\mathrm{Al}^{3+}, \mathrm{Ga}^{3+}, \mathrm{Fe}^{3+}, \mathrm{Cr}^{3+}\right.$, etc. $)$ cations and the interlayer anions [5-9]. After calcination at an appropriate temperature, LDHs can transform into mixed solid solution, i.e., a homogeneous phase consisting of $\mathrm{M}^{3+}-\mathrm{M}^{2+}$ oxide, and the adsorption capacity of calcined LDH can be markedly enhanced over that of the original LDH. The enhanced adsorption capacity is generally attributed to a «memory effect» when the layered structure is reconstructed in association with the mixed $\mathrm{M}^{3+}-\mathrm{M}^{2+}$ solid solution and the aqueous anions can be concomitantly absorbed into the interlayers of the restored LDH [4].

Calcined LDHs with the properties noted above have been extensively used as sorbents for the sorption of organic pollutants, such as glyphosate, 4-chloro-2-methylphenoxyacetic acid, sodium dodecylbenzenesulfonate, dicamba, and acidic pesticides [10-13]. Adsorption into LDH was found to occur on the external surface or/and in the interlayer space, the location being dependent on the interlayer anions. Adsorption by calcined LDH was markedly higher compared to that by LDH. In addition, once used LDH sorbents, could be feasibly regenerated [14]. 
In this study, $\mathrm{Zn}$ - $\mathrm{Al}$ mixed oxides, as well as $\mathrm{Zn}$ $\mathrm{Al} \mathrm{LDH}$ were prepared and used as the sorbents for adsorption of TC from water to elucidate the adsorption behavior of TC to mixed oxides and LDH.

\section{EXPERIMENTAL}

Mixed $\mathrm{Zn}-\mathrm{Al}$ oxides were synthesized by citrate method according to [15]. Metal nitrates (hydrates) were mixed with citric acid and $\mathrm{H}_{2} \mathrm{O}$ in a molar ratio $\left(\mathrm{Zn}^{2+}+\mathrm{Al}^{3+}\right): \mathrm{C}_{6} \mathrm{H}_{8} \mathrm{O}_{7} \cdot \mathrm{H}_{2} \mathrm{O}: \mathrm{H}_{2} \mathrm{O}=$ $(0.33+0.67): 2.05: 1.2$ and the mixture was heated with stirring to obtain a polymeric foam mass. The thermal treatment was performed at $200-250{ }^{\circ} \mathrm{C}-$ $2 \mathrm{~h}, 300-400-1 \mathrm{~h}, 400-600^{\circ} \mathrm{C}-2 \mathrm{~h}$. The sample was indicated as $\mathrm{ZnAl}_{21}$.

Mixed $\mathrm{Zn}$-Al oxides obtained as described above were hydrated by treatment with excess of water for $24 \mathrm{~h}$ at room temperature under stirring. Hydrated samples were dried at $100^{\circ} \mathrm{C}$ in air. The sample were indicated as $\mathrm{ZnAl}_{21} / \mathrm{H}_{2} \mathrm{O}$. The samples obtained by hydration of mixed oxides with aqueous TC solution at the same conditions were indicated as $\mathrm{ZnAl}_{21} / \mathrm{H}_{2} \mathrm{O} / \mathrm{TC}$.

ZnAl LDH with a $\mathrm{M}^{2+} / \mathrm{M}^{3+}$ molar ratio of 2 were obtained according to the standard coprecipitation method [5] as follows. Two solutions were prepared. Solution 1 contained 0.4 mole of zinc nitrate and 0.2 mole of aluminum nitrate in total volume of $1 \mathrm{~L}$. Solution 2 contained 0.5 mole of sodium carbonate $\left(\mathrm{Na}_{2} \mathrm{CO}_{3}\right)$ and 1.5 mole of sodium hydroxide in total volume of $1 \mathrm{~L}$. $0.5 \mathrm{~L}$ of water was placed into a 3-L glass reactor equipped with stirrer and water bath. Solutions 1 and 2 were slowly pored into the reactor with equal rate at stirring (room temperature). After complete addition of the reagents, the $\mathrm{pH}$ of the solution over precipitate was 10. Then, temperature was raised up to $85^{\circ} \mathrm{C}$ and the suspension was being kept for $6 \mathrm{~h}$ at this temperature under continuous stirring. Next day, the precipitate was filtered, washed with water and dried at $120^{\circ} \mathrm{C}$.

XRD patterns of samples were recorded with DRON-4-07 diffractometer $\left(\mathrm{Cu} K_{\alpha}\right.$ radiation). Calculation of apparent crystallite size for $\mathrm{ZnO}$ and LDH has been performed by Debye-Scherrer formula $\beta(2 \theta)=0.94 \lambda /\left(D \cos \theta^{\circ}\right)$ using (100) reflections for $\mathrm{ZnO}$ and (110) reflection for $\mathrm{LDH}$, employing the FWHM procedure.

Nitrogen adsorption and desorption isotherms at $77 \mathrm{~K}$ were measured on a Quantachrome Nova 2200 e Surface Area and Pore Size Analyzer. Prior to analysis, the samples were degassed in vacuum at $120^{\circ} \mathrm{C}$ for $20 \mathrm{~h}$.
For the investigation of the TC complexation with $\mathrm{Al}^{3+}$ aqueous stock solutions of tetracycline hydrochloride and aluminium chloride were prepared. All the experiments were carried out at room temperature $\left(20 \pm 1^{\circ} \mathrm{C}\right)$ using freshly prepared TC solutions. The total concentration TC was $5 \times 10^{-5} \mathrm{~mol} \mathrm{~L}^{-1}$. The molar ratio of TC: $\mathrm{Al}^{3+}$ varied from 1:0.25 to 1:25. The $\mathrm{pH} 7$ of aqueous solutions was adjusted by $0.01 \mathrm{M}$ solutions of $\mathrm{NaOH}$ and $\mathrm{HCl}$.

TC adsorption isotherms for the adsorbents were determined using a batch adsorption approach. Typically, $0.05 \mathrm{~g}$ freshly $\mathrm{Zn}-\mathrm{Al}$ mixed oxides and LDHs were introduced into $100-\mathrm{mL}$ glass tubes containing $40 \mathrm{~mL}$ of freshly prepared aqueous TC solutions with concentrations ranging from $2 \times 10^{-5} \mathrm{~mol} \mathrm{~L}^{-1}$ to $5 \times 10^{-5} \mathrm{~mol} \mathrm{~L}^{-1}$. The adsorption process was allowed to last $24 \mathrm{~h}$ under continuous stirring. Particles were removed by centrifugation at 600 RPM (rounds per minute), and the residual concentration of TC in the solution was determined using UV-Vis spectrometry at a detecting wavelength of $375 \mathrm{~nm}$. The equilibrium adsorption amount of TC in the sample was calculated according to equation: $a_{\mathrm{e}}=\left(C_{0}-C_{\mathrm{e}}\right) V / m$, where $a_{\mathrm{e}}$ is the amount of $\mathrm{TC}$ adsorbed at equilibrium $(\mathrm{mg} / \mathrm{g}), C_{0}, C_{\mathrm{e}}$ are the initial and equilibrium TC concentrations in solution $(\mathrm{mg} / \mathrm{L}), V$ is the total volume of solution, and $m$ is the sorbent mass.

\section{RESULTS AND DISCUSSION}

The XRD analysis was applied to investigate the structure of mixed oxides and LDH. XRD patterns of the mixed oxides refer to pure phase wurtzite $\mathrm{ZnO}$ with a hexagonal lattice (Fig. $1 a$ ). The narrow peaks in the X-ray diffraction patterns indicate on the highly crystalline structure of the samples. No diffraction peaks relating to the crystalline alumina modifications are observed. Evidently, the processing mode of citric method excludes the formation of low-temperature modifications of $\mathrm{Al}_{2} \mathrm{O}_{3}$, produced by calcination at $500-700{ }^{\circ} \mathrm{C}$ [16]. Hydration of $\mathrm{ZnAl}_{21}$ oxides in aqueous suspension for $24 \mathrm{~h}$ under stirring leads to a partial transformation of the mixed oxides to LDH (Fig. 1 a). Some part of mixed oxides was transformed to $\mathrm{Zn}-\mathrm{Al} \mathrm{LDH}$, when stirred in TC solution over $24 \mathrm{~h}$ (Fig. 1 a). The XRD patterns of $\mathrm{Zn}-\mathrm{Al} \mathrm{LDH}$ synthesized by a conventional coprecipitation and dried at $120{ }^{\circ} \mathrm{C}$ correspond to LDH structure in carbonate form (pristine) (Fig. $1 b$ ). LDH structure is completely destroyed at $250{ }^{\circ} \mathrm{C}$ (Fig. $1 \mathrm{~b}$ ). Defect structure of wurtzite 
$\mathrm{ZnO}$ is formed with the increase in the calcination temperature to $600{ }^{\circ} \mathrm{C}$ (Fig. 1 b). Hydration of the sample calcined at $600{ }^{\circ} \mathrm{C}$ leads to the reconstruction of its original layered structure (Fig. $1 b$ ). The minor amount of $\mathrm{ZnO}$ in reconstructed $\mathrm{Zn}-\mathrm{Al} \mathrm{LDH}$ is still observed.

The lattice parameters calculated from the XRD patterns of $\mathrm{Zn}-\mathrm{Al} \mathrm{LDH}$ are listed in Table 1. The interplanar distance determined by Bragg equation with using the peak at (003) orientation corresponds to the presence of carbonate ions in anionic layer [17]. The differences in the values of LDH unit cell parameters of samples synthesized by citrate and coprecipitation methods and hydrated in aqueous suspensions were not observed (Table 1). The lattice parameter $a$ is a characteristic of the average metal-metal distance within the brucite-like layers. The value of $a$ has been calculated using the (110) reflection and it is close to the value of this parameter for brucite $(3.10 \AA)$ (Table 1). The interlayer distance of $\mathrm{ZnAl} / \mathrm{H}_{2} \mathrm{O} / \mathrm{TC}$ sample is higher in comparison with those of $\mathrm{ZnAl}_{21} / \mathrm{H}_{2} \mathrm{O}$ and $\mathrm{ZnAl}_{21} \mathrm{LDH}$ that could be explained by formation of intercalated compounds. Reconstruction of mixed oxides in LDH is often used to introduce a wide variety of organic anions in LDH interlayer space [18]. According to [19] the molecular dimension of TC was estimated to be $1.41 \times 0.78 \times 0.24 \mathrm{~nm}^{3}$. Therefore, the interlayer dimension of $\mathrm{ZnAl} / \mathrm{H}_{2} \mathrm{O} / \mathrm{TC}$ is smaller than the length and breadth of the TC molecule, suggesting that TC molecules, if present in the interlayer, could lie parallel to the brucite-like layers in $\mathrm{ZnAl} / \mathrm{H}_{2} \mathrm{O} / \mathrm{TC}$ [19].
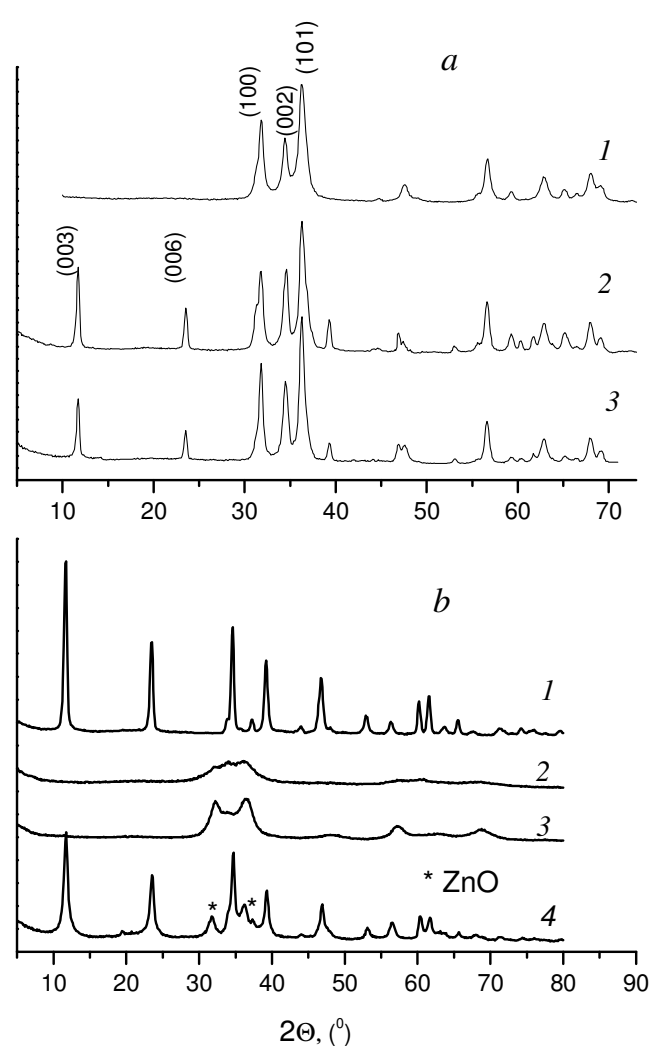

Fig. 1. X-ray diffraction patterns of samples. (a) Zn-Al mixed oxides synthesized by citrate method: $\mathrm{ZnAl}_{21}-1 ; \mathrm{ZnAl}_{21} / \mathrm{H}_{2} \mathrm{O}$, hydrated under stirring over $24 \mathrm{~h}-2 ; \mathrm{ZnAl} / \mathrm{H}_{2} \mathrm{O} / \mathrm{TC}$, hydrated under stirring over $24 \mathrm{~h}$ in TC solution - 3; (b) Synthesized by coprecipitation method: $\mathrm{Zn}-\mathrm{Al}$ $\mathrm{LDH}$ as prepared -1 ; sintered at $250^{\circ} \mathrm{C}-2$; $600{ }^{\circ} \mathrm{C}-3$; sintered at $600{ }^{\circ} \mathrm{C}$ and rehydrated under stirring over $24 \mathrm{~h}-4$

Table 1. Structural properties of LDH

\begin{tabular}{|c|c|c|c|c|c|c|}
\hline \multirow{2}{*}{ Sample } & \multirow{2}{*}{$\begin{array}{l}\text { Synthesis } \\
\text { method }\end{array}$} & \multicolumn{2}{|c|}{$\begin{array}{c}\text { Parameters of crystal } \\
\text { latice, } \mathbf{n m} \\
\end{array}$} & \multirow{2}{*}{$d_{003, \mathrm{~nm}}$} & \multirow{2}{*}{$\begin{array}{c}\text { Interlayer } \\
\text { distance } * * *\end{array}$} & \multirow{2}{*}{$\begin{array}{c}\text { LDH } \\
\text { crystal } \\
\text { size, } \mathbf{n m}\end{array}$} \\
\hline & & $a^{*}$ & $c^{* *}$ & & & \\
\hline $\mathrm{ZnAl}_{21} / \mathrm{H}_{2} \mathrm{O}$ & Citrate & 0.306 & 2.283 & 0.761 & 0.281 & 21.5 \\
\hline $\mathrm{ZnAl} / \mathrm{H}_{2} \mathrm{O} / \mathrm{TC}$ & Citrate & 0.311 & 2.289 & 0.767 & 0.287 & 23.0 \\
\hline $\mathrm{ZnAl}_{21} \mathrm{LDH}$ & Coprecipitation & 0.307 & 2.250 & 0.750 & 0.270 & 16.1 \\
\hline
\end{tabular}

$a=2 d_{110} ; * * c=3 d_{003} ; * * *$ Interlayer distance $=d_{003}-$ thickness of layer $(0.48 \mathrm{~nm})$ [17].

The porous structure of the samples was characterized by nitrogen adsorption/desorption isotherms (Fig. $2 a$ ). Isotherms of the samples are type IV according to the classification of IUPAC. The hysteresis of isotherms is of type $\mathrm{H} 3$ that is characteristic for slit-shaped pores [20]. The BET surface area of mixed oxides $\mathrm{ZnAl}_{21}$ is $29 \mathrm{~m}^{2} / \mathrm{g}$. The hydration of $\mathrm{ZnAl}_{21}$ under the stirring resulted in partial reconstructed mixed oxides $\mathrm{ZnAl}_{21} / \mathrm{H}_{2} \mathrm{O}$ with two times higher surface area $\left(63 \mathrm{~m}^{2} / \mathrm{g}\right)$, while for $\mathrm{Zn}-\mathrm{Al} \mathrm{LDH}$ synthesized by coprecipitation method the surface area was $31 \mathrm{~m}^{2} / \mathrm{g}$. The increasing of surface area of the hydrated material could be produced by exfoliation of reconstructed $\mathrm{Zn}-\mathrm{Al} \mathrm{LDH}$ crystals during the mechanical stirring [21]. 
The pore size distribution of the samples was studied by analyzing the desorption branch of the isotherms using the $\mathrm{BJH}$ method. For $\mathrm{ZnAl}_{21}$ sample a wide pore sizes distribution in the range of 2-70 nm with a maximum about $9 \mathrm{~nm}$ was observed (Fig. 2 b). Hydrated sample $\mathrm{ZnAl}_{21} / \mathrm{H}_{2} \mathrm{O}$ possessed of two types of pores with a narrow $(1.5-2 \mathrm{~nm})$ and wide $(4-80 \mathrm{~nm})$ pore radius distribution (Fig. $2 b$ ). The total pore volume of $\mathrm{ZnAl}_{21}$ and $\mathrm{ZnAl}_{21} / \mathrm{H}_{2} \mathrm{O}$ is similar $\left(0.14 \mathrm{~cm}^{3} / \mathrm{g}\right)$. LDH obtained by coprecipitation had a broad pore radius distribution of 5-70 nm (maximum $31 \mathrm{~nm}$ ) (Fig. $2 b$ ) and a total pore volume of $0.26 \mathrm{~cm}^{3} / \mathrm{g}$.

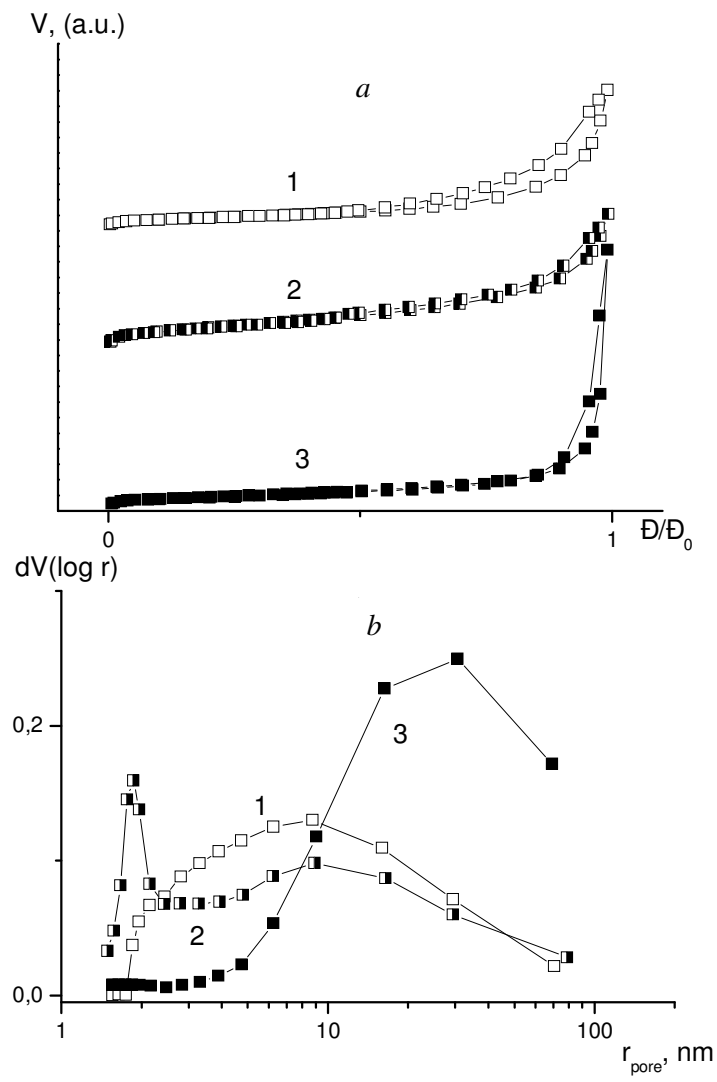

Fig. 2. (a) Nitrogen adsorption-desorption isotherms and (b) pore size distribution of $\mathrm{ZnAl}_{21}-1$, $\mathrm{ZnAl}_{21} / \mathrm{H}_{2} \mathrm{O}-2, \mathrm{ZnAl}_{21} \mathrm{LDH}-3$

The UV/vis absorption spectra of tetracyclines are generally discussed as superposition of the contributions of two separated chromophores [22-24]: the first is the so-called A chromophore which comprises a tricarbonylmethane keto-enol system spanning from $\mathrm{C} 1$ to $\mathrm{C} 3$ including the substituents $(\mathrm{O} 1$, carboxamide group at $\mathrm{C} 2$ and $\mathrm{OH} 3$ ); the second, usually termed the $\mathrm{BCD}$ chromophore, comprises the $\pi$-electron system located on rings $\mathrm{B}, \mathrm{C}$ and $\mathrm{D}$ (Fig. $3 a$ ). The absorption spectrum, in the UV-visible region, of an acid solution of TC displays three bands centered at 218, 270 and $356 \mathrm{~nm}$. According to [22], the $\pi-\pi^{*}$ transition of the tricarbonyl system of the A-ring contributes only to the band at $270 \mathrm{~nm}$ while the $\pi-\pi^{*}$ transition of the BCD chromophore contributes to all three bands. These transitions are sensitive to deprotonation and metal coordination. Three values of the dissociation constants $\left(\mathrm{pK}_{\mathrm{a} 1} \approx 3.4 ; \mathrm{pK}_{\mathrm{a} 2} \approx 7.5 ; \mathrm{pK}_{\mathrm{a} 3} \approx 9.3\right)$ have been determined experimentally [23] that correspond to existence of the protonated, neutral zwitterionic, monoanionic, and dianionic forms of TC (Fig. $3 b$ ). In presented work TC adsorption study was conducted at $\mathrm{pH} 7.0$ when aqueous TC consists of about $70 \%$ zwitterionic species and $30 \%$ anionic species [24].

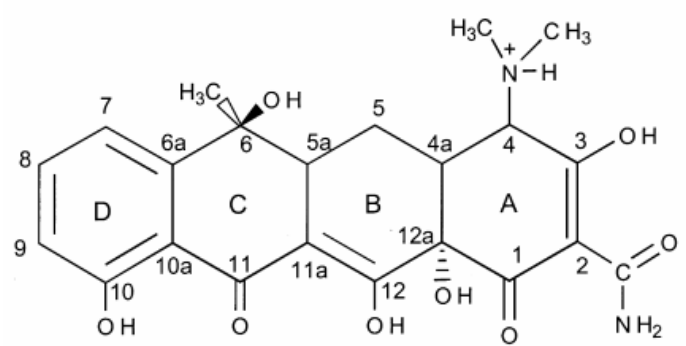

a

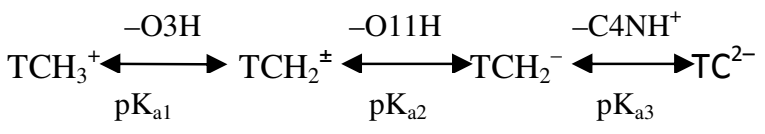

b

Fig. 3. (a) Chemical structure of tetracycline; (b) scheme of TC protonation/deprotonation

The changes in the absorption spectra of TC were detected after contact of mixed oxides and LDH with TC solution which could be explained by the interaction of TC with oxides and LDH (Fig. 4).

The strong metal-binding tendency of TC plays an important role in contributing to their strong interactions with mineral surfaces [25-30]. TC forms complexes with di- and trivalent metal cations [25]. To get evidence of TC interaction with $\mathrm{Zn}^{2+}$ or $\mathrm{Al}^{3+}$, extracted from mixed oxides and LDH the absorption spectra of TC aqueous solutions containing $\mathrm{Zn}^{2+}$ and $\mathrm{Al}^{3+}$ cations were analyzed. No changes were observed in TC absorption spectra in the presence of $\mathrm{Zn}^{2+}$ ions in 
the range of molar ratios $[\mathrm{TC}]:\left[\mathrm{Zn}^{2+}\right]$ ranging from 0.5 to 50 .

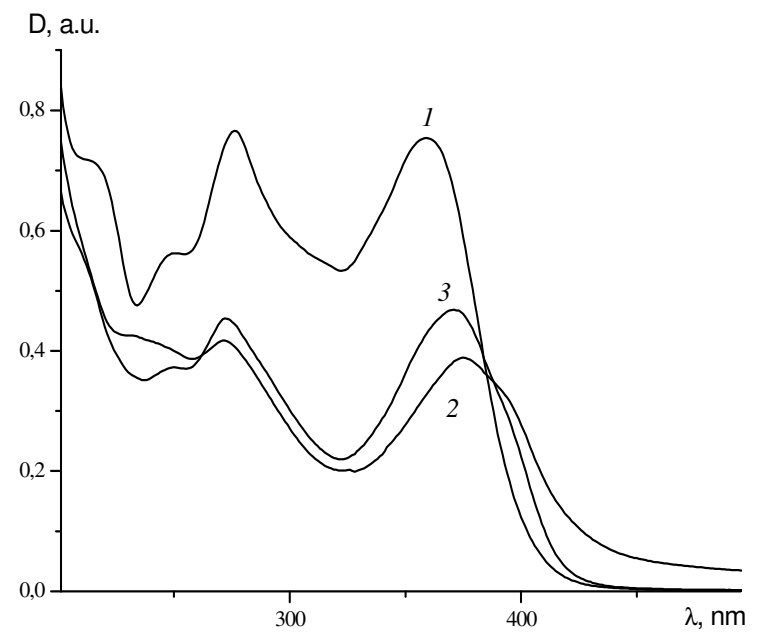

Fig. 4. UV-visible spectra of $5 \times 10^{-5} \mathrm{M}$ TC solution before adsorption - 1 ; after the interaction with: $\mathrm{ZnAl}_{21}-2 ; \mathrm{ZnAl} \mathrm{LDH} \mathrm{-} 3$

$\left(\left[\mathrm{ZnAl}_{21}\right]=\left[\mathrm{ZnAl}_{21} \mathrm{LDH}\right]=400 \mathrm{mg} / \mathrm{l}\right)$

The absorption spectra of TC have been changed in the presence of $\mathrm{Al}^{3+}$ at the molar ratio of $[\mathrm{TC}]:\left[\mathrm{Al}^{3+}\right]$ ranging from 1 to 13 . Two types of changes of TC spectra were observed as dependent on the molar ratio of $[\mathrm{TC}]:\left[\mathrm{Al}^{3+}\right]$. In the first place, in the molar ratio of TC:Al ${ }^{3+}$ ranging from 1 to 1.25 the absorption band at $357 \mathrm{~nm}$ has been shifted up to $375 \mathrm{~nm}$; the minimum in the absorption spectrum at $234 \mathrm{~nm}$ has been significantly decreased. According to [26] the absorption spectra of TC at the ratio $\mathrm{TC}: \mathrm{Al}^{3+}=1.25$ corresponds to the absorption bands of monoanionic TC. Therefore, it could be assumed that at the molar ratios $\left[\mathrm{TC}: \mathrm{Al}^{3}\right]^{+} 1: 1$ and 1:1.25 complexes TC/Al $^{3+} 1: 1$ were formed. It is possible that complexes TC/Al ${ }^{3+}$ 2:1 were formed, particularly when the ratio $[\mathrm{TC}]:\left[\mathrm{Al}^{3+}\right]$ was less than 1 reported TC complexes of trivalent metal ions were to have the composition TC/Me ${ }^{3+}$ 2:1 [27]. In the second place, the further red shift of the absorption band at $357 \mathrm{~nm}$ up to $381 \mathrm{~nm}$ has been observed and the appearance of a new peak at $234 \mathrm{~nm}$ was detected at the molar ratio of $[\mathrm{TC}]:\left[\mathrm{Al}^{3+}\right]$ ranging from 1.25 to 13 . These adsorption spectra changes according to [26] correspond to the formation of the TC dianion. Therefore, in this case complexes TC/Al ${ }^{3+}$ 1:2 have been formed.

Based on the absorption spectra of TC, and according to [28], one can assume that the formation of complexes $\mathrm{TC}^{\mathrm{A}} \mathrm{l}^{3+}=2: 1$ and $1: 1$ is mediated by keto-enol group of the $\mathrm{BCD}$ chromophore of TC molecule on C11, C11a and
C12. The formations of the complex bind with the second ion $\mathrm{Al}^{3+}$ occurs by involving a groups -C4-NH and C3O A chromophore [29].
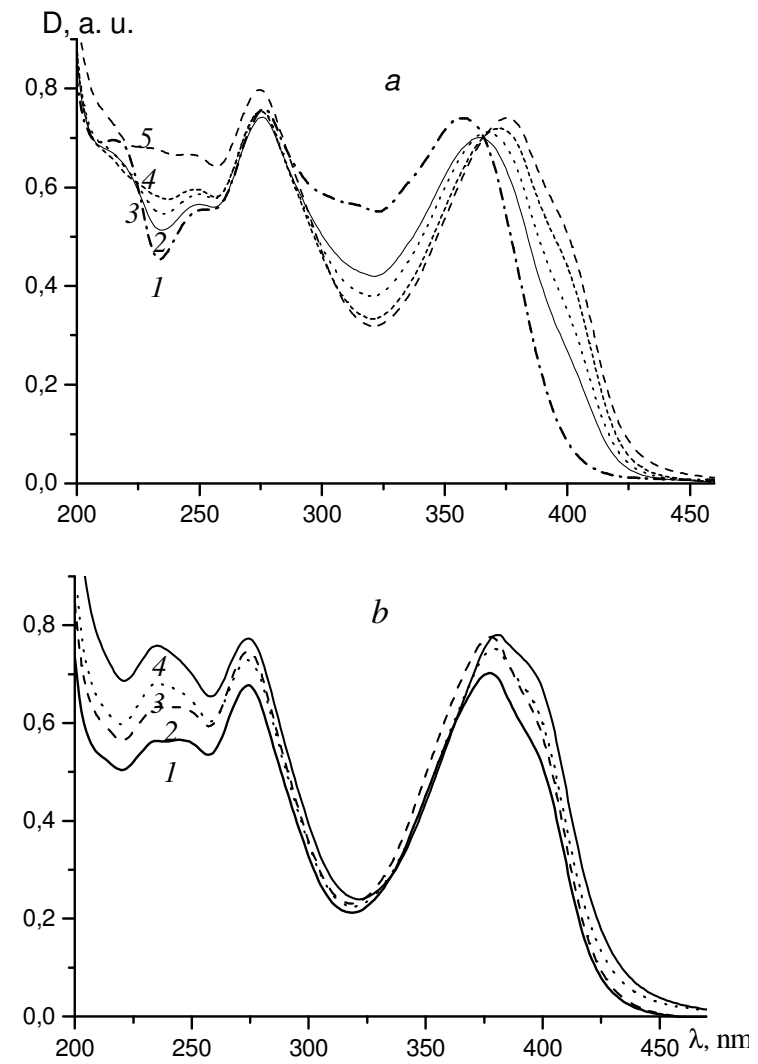

Fig. 5. UV-visible spectra of $5 \times 10^{-5} \mathrm{M}$ TC solution in the presence of $\mathrm{Al}^{3+}$ at the molar ratio $[\mathrm{TC}]:\left[\mathrm{Al}^{3+}\right]$ : (a) $1: 0-1 ; 1: 0.3-2 ; 1: 0.6-3 ; 1: 1-4 ; 1: 1.25-5$; (b) $1: 2.5-1 ; 1: 3-2 ; 1: 5-3 ; 1: 13-4$

TC spectra after the contact of its solution with mixed oxides exhibited adsorption bands which correspond to complexes TC/Al ${ }^{3+}$ 1:1 (Fig. 6). The ligand-promoted dissolution has been observed during TC sorption to the hydrous oxides of $\mathrm{Al}$ and $\mathrm{Fe}$ [30]. The complex formation was more significant for aluminium hydrous oxides and complexes TC/Al 1:1 and 1:2 have were formed [30]. So, the TC adsorption on $\mathrm{Zn}-\mathrm{Al}$ mixed oxides and $\mathrm{Zn}-\mathrm{Al} \mathrm{LDH}$ is accompanied by ligandpromoted leaching of $\mathrm{Al}^{3+}$ from mixed oxides.

It was found that optical density of TC solution has been abruptly decreased within $30 \mathrm{~min}$ of TC adsorption study experiment. $58 \%$ of TC amount in $5 \times 10^{-5} \mathrm{M}$ solution was adsorbed by mixed oxides at this time, after that the increase of TC content up to $5 \%$ was observed in the solution due to the formation of soluble TC complexes with $\mathrm{Al}^{3+}$ ions derived from the matrix oxides. After the 
establishment of the equilibrium $54 \% \mathrm{TC}$ was adsorbed from solution by mixed oxides. The leaching of $\mathrm{Al}^{3+}$ by complexation with TC was observed for both samples. If one assume that complexes TC/Al 1:1 and 1:2 have been formed after TC interaction with mixed oxides and LDH, the percentage of leached $\mathrm{Al}^{3+}$ ions are 1.5-2\%.

Langmuir, Freundlich, and DubininRadushkevich models have been used to describe the equilibrium characteristics of adsorption. The Lagmuir model assumes the formation of adsorbate monolayer on the outer surface of the adsorbent. Based upon these assumptions, Langmuir represented the following equation: $a_{e}=K_{L} C_{e} /\left(1+a_{m} C_{e}\right)$, where $a_{e}$ - the amount of TC adsorbed per gram of the adsorbent at equilibrium $(\mathrm{mg} / \mathrm{g}), \quad C_{e} \quad-$ equilibrium TC concentrations $(\mathrm{mg} / \mathrm{L}), \mathrm{K}_{\mathrm{L}}-$ maximum monolayer coverage capacity $(\mathrm{mg} / \mathrm{g})$. The adsorption parameters were determined by transforming the Langmuir equation into linearized form: $C_{e} / a_{e}=1 / K_{L} a_{m}+C_{e} / a_{m}$ and were calculated from the slope and intercept of the linear plot of $1 / a_{e}$ vs. $1 / C_{e}$.

The Freundlich model is commonly used to describe the adsorption characteristics for the heterogeneous surface. These data fit the empirical equation $a_{e}=K_{F} C_{e}{ }^{l / n}$, where $C_{e}-$ equilibrium TC concentrations, $\mathrm{mg} / \mathrm{L}, \mathrm{K}_{\mathrm{F}}-$ Freundlich isotherm constant $(\mathrm{mg} / \mathrm{g}) \quad n-$ adsorption intensity. The linearized form of Freundlich equation is: $\log a_{e}=\log K_{F}+(1 / n) \log C_{e}$. The adsorption parameters were obtained from the plots of $\log a_{e}$ vs. $\log C_{e}$.

Dubinin-Radushkevich isotherm is generally applied to express the adsorption mechanism with a Gaussian energy distribution onto a heterogeneous surface. The model is represented by the equation: $a_{e}=a_{D} \exp \left(-K_{D} R T \ln \left(1+1 / C_{e}\right)\right)$, where $K_{D}$ - the isotherm constant, is related to the free energy of sorption per mole of the sorbate, $a_{D}-$ is the Dubinin-Radushkevich isotherm constant related to the degree of sorbate sorption by the sorbent surface, $\mathrm{R}$ the gas constant $(8.314 \mathrm{~J} / \mathrm{mol} \mathrm{K}), \mathrm{T}$ and $\mathrm{C}_{\mathrm{e}}$ represent, absolute temperature $(\mathrm{K})$ and adsorbate equilibrium concentration $(\mathrm{mg} / \mathrm{L})$, respectively. The linear form of equation is given as $\ln \mathrm{a}_{\mathrm{e}}=\ln \mathrm{a}_{\mathrm{D}}$ $-2 \mathrm{~K}_{\mathrm{D}} \mathrm{RT} \ln \left(1+1 / \mathrm{C}_{\mathrm{e}}\right)$. The adsorption parameters were obtained from the plots of $\ln a_{e}$ vs. RT $\ln (1+$ $\left.1 / C_{e}\right)$. The free energy of adsorption $\left(E_{D}\right)$ from Dubinin-Radushkevich isotherm model can be calculated using the relation $E_{D}=\left(-2 K_{D}\right)^{-0.5}$.
The isotherms for adsorption of TC onto mixed oxides and LDHs at pH 7.0 are shown in Fig. 6.

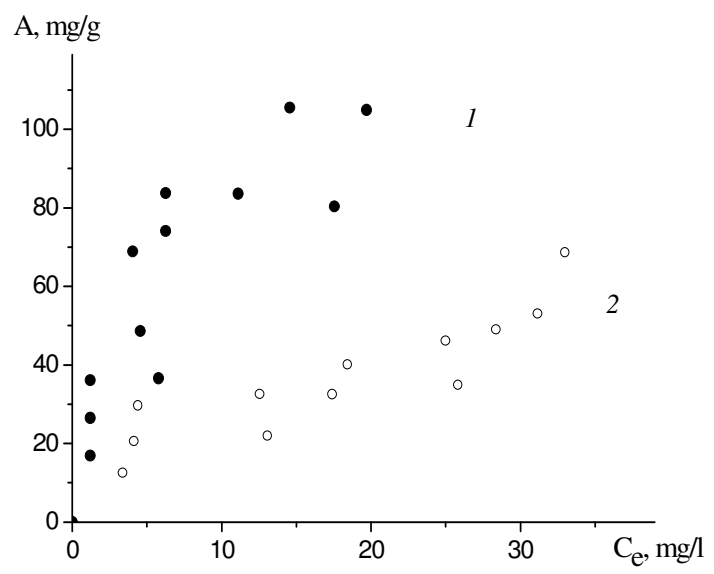

Fig. 6. Adsorption isotherms of tetracycline by mixed oxides $\mathrm{ZnAl}_{21}-1$ and $\mathrm{ZnAl}_{21}$ LDHs - 2

The Langmuir and Freundlich isotherm parameters are listed in Table 2. Both equations fit the experimental data fairly well as indicated by the values of correlation coefficients.

The processes of TC adsorption on the surface of mixed oxides and LDH can be described by Langmuir and Freundlich models (Table 2). Correlation coefficient of Langmuir model is higher for TC adsorption on mixed oxides. This could be explained by the dominance of sorption sites of a certain type, in particular $\equiv \mathrm{Al}-\mathrm{OH}_{2}{ }^{+0.5}$ or $\equiv \mathrm{Al}-\mathrm{OH}_{2}$ [30]. TC adsorption on LDH is better described by the Freundlich model, which assumes heterogeneity of the surface. Values of the parameter $1 / n$, which characterizes the intensity of adsorbent-adsorbate interactions, are about the same for both samples. The fractional value of $1 / n$ $[0<(1 / n)<1]$ indicates that weak adsorptive forces are effective on the surface of mixed oxides and LDH [31]. Most likely, for both samples TC adsorption occurs on Al-containing sites. The presented above study of TC complexation with $\mathrm{Al}^{3+}$ in solution and data from the study of TC adsorption on Al-containing zeolites [32] confirm this suggestion.

Dubinin-Radushkevich model is more general than Langmuir one, as it does not assume homogeneity of the surface or constant adsorption potential. This model indicates on the nature of adsorption and can be used to calculate the average free energy of adsorption $\mathrm{E}_{\mathrm{D}}$ [32].

The calculated values of $E_{D}$ for samples are less than $8 \mathrm{~kJ} / \mathrm{mol}$ (Table 2) indicating a physisorption process [33]. 
It should be noted that the adsorption capacity of the samples $\mathrm{ZnAl}_{21}$ and $\mathrm{ZnAl}_{21} \mathrm{LDH}$ are not dependent on their morphological characteristics. The surface area and pore size for the mixed oxides $\mathrm{ZnAl}_{21}$ and $\mathrm{ZnAl}_{21} \mathrm{LDH}$ approximately identical and the pore volume is almost 2 times higher for $\mathrm{ZnAl}_{21} \mathrm{LDH}$. As indicated above, the partial recovery of LDH structure has been occurring under stirring of the mixed oxides aqueous slurry over 24 hours (Fig. $1 a$, pattern 2 ), that could affect the TC adsorption process. The surface area of
$\mathrm{ZnAl}_{21} / \mathrm{H}_{2} \mathrm{O}$ sample obtained by hydration of mixed oxides under stirring is two times higher than the initial surface area of the mixed oxides. Slightly fewer LDH phase is formed under stirring of suspension of mixed oxides in TC solution (Fig. $1 a$, pattern 3). Consequently, in the process of TC adsorption under stirring the texture of $\mathrm{ZnAl}_{21}$ undergoes changes that lead to the formation of the sample with the highest adsorptive capacity.

Table 2. Langmuir, Freundlich, and Dubinin-Radushkevich isotherm constants for TC adsorption onto mixed oxides and LDHs

\begin{tabular}{|c|c|c|c|c|c|c|c|c|c|c|}
\hline \multirow[b]{2}{*}{ Sample } & \multicolumn{3}{|c|}{ Langmuir } & \multicolumn{3}{|c|}{ Freundlich } & \multicolumn{4}{|c|}{ Dubinin-Radushkevich } \\
\hline & $\begin{array}{c}a_{\infty} \\
\mathbf{m g} / \mathbf{g}\end{array}$ & $\begin{array}{c}K_{\mathrm{L}}, \\
\mathrm{l} / \mathrm{mmol}\end{array}$ & $R^{2}$ & $\begin{array}{c}K_{\mathrm{F}}, \\
(\mathbf{m m o l} / \mathbf{g}) \times \\
(\mathrm{l} / \mathrm{mmol})^{1 / \mathbf{n}}\end{array}$ & $1 / n$ & $R^{2}$ & $\begin{array}{c}K_{\mathrm{D},} \\
\mathrm{mol}^{2} / \mathrm{K} \mathbf{J}^{2}\end{array}$ & $\begin{array}{c}a_{\infty} \\
\mathbf{m g} / \mathbf{g}\end{array}$ & $R^{2}$ & $\begin{array}{c}E_{D}, \\
\kappa \mathrm{J} / \mathrm{mol}\end{array}$ \\
\hline $\mathrm{ZnAl}_{21}$ & 134.65 & 86.0 & 0.91 & 1.50 & 0.55 & 0.85 & 0.564 & 213.45 & 0.86 & 7.14 \\
\hline $\mathrm{ZnAl}_{21} \mathrm{LDH}$ & 81.75 & 30.5 & 0.79 & 0.45 & 0.51 & 0.83 & 0.012 & 87.60 & 0.83 & 6.51 \\
\hline
\end{tabular}

As was mentioned above, the intercalation of TC molecules in interlayer space of LDH takes place under hydration of mixed oxides in TC solution. $\mathrm{Zn}-\mathrm{Al} \mathrm{LDH}$ surface has a positive charge due to isomorphic substitution of $\mathrm{Zn}^{2+}$ ions by $\mathrm{Al}^{3+}$ ions. Positive charge balancing anions are located in interlayer space of LDH. Therefore, negatively charged form of TC can be integrated into interlayer space as charge compensating anions. The influence of this phenomenon on TC adsorption is negligible. If $\mathrm{ZnAl}_{21}$ were completely reconstructed on TC adsorption (with a theoretical formula of $\left.\left[\mathrm{Zn}_{0.66} \mathrm{Al}_{0.33}(\mathrm{OH})_{2}\right](\mathrm{TC})_{0.33}\right)$ and if electrostatic retention of $\mathrm{TC}$ as due to isomorphic substitution of $\mathrm{Al}$ for $\mathrm{Zn}$, the theoretical adsorption amount of $\mathrm{TC}$ in the interlayers of the reconstructed $\mathrm{Zn}-\mathrm{Al} \mathrm{LDH}$ would be $6 \mathrm{~g} / \mathrm{g}$, which is approximately 60 times greater than the observed adsorption amount. This suggests that the content of the reconstructed $\mathrm{Zn}-\mathrm{Al} \mathrm{LDH}$ in $\mathrm{ZnAl} / \mathrm{H}_{2} \mathrm{O} / \mathrm{TC}$ is low. In addition, the intensity of the (003), (006), and (009) diffraction peaks, characteristic of reconstructed $\mathrm{LDH}$, is markedly lower than that of $\mathrm{ZnAl}_{21} \mathrm{LDH}$ indicative of the low content of reconstructed $\mathrm{LDH}$ in $\mathrm{ZnAl} / \mathrm{H}_{2} \mathrm{O} / \mathrm{TC}$ (Fig. $1 a$ ). Considering the low $\mathrm{LDH}$ content in $\mathrm{ZnAl} / \mathrm{H}_{2} \mathrm{O} / \mathrm{TC}$ and lower TC adsorption to $\mathrm{LDH}, \mathrm{TC}$ adsorption on the external surface of restored LDH particles is small. The greater part of TC is adsorbed on the internal surface of the mixed oxides. It is suggested that adsorption preferably occurs on $\mathrm{Al}_{2} \mathrm{O}_{3}$ surfaces. The substitution of carbonate ions of LDH on TC by ion exchange is unlikely, as carbonate anions block access to the interlayer region [34]. TC will be adsorbed on the external surface of the LDH.

\section{CONCLUSIONS}

$\mathrm{Zn}-\mathrm{Al}$ mixed oxides and $\mathrm{Zn}-\mathrm{Al} \mathrm{LDH}$ were used as the sorbents for TC in water. $\mathrm{Zn}-\mathrm{Al}$ mixed oxides have a higher adsorption capacity as compared with $\mathrm{Zn}-\mathrm{Al} \mathrm{LDH}$. In aqueous suspension, during TC adsorption, the structure of $\mathrm{Zn}-\mathrm{Al}$ mixed oxides was partially restored and a significant content of $\mathrm{Zn}-\mathrm{Al}$ oxide solid remained. Tetracycline is adsorbed on the external surfaces of $\mathrm{Zn}-\mathrm{Al}$ mixed oxides and LDH. The parameters of $\mathrm{TC}$ adsorption by $\mathrm{Zn}-\mathrm{Al}$ mixed oxides and LDHs were calculated with using standard mathematical models of Langmuir, Freundlich and DubininRadushkevich. It was found that adsorption of TC on $\mathrm{Zn}$-Al mixed oxides and $\mathrm{Zn}$-Al LDH occurs on the sites of one particular type and has a physical nature. Considering the present of TC contaminants in aquatic environments, $\mathrm{Zn}-\mathrm{Al}$ mixed oxides may find specific applications in the removal of TC from water. 


\title{
Адсорбція тетрацикліну $\mathrm{Zn}-\mathrm{Al}$ змішаними оксидами та шаруватими подвійними гідроксидами
}

\author{
Г.М. Старух
}

Інститут хімії поверхні ім. О.О. Чуйка Наџіональної академії наук України вул. Генерала Наумова, 17, Київ, 03164, Україна, starukh_galina@ukr.net

Вивчено адсорбиію тетрацикліну (ТЦ) з водних розчинів на поверхні Zn-Al зміманих оксидів. Встановлено, що в прочесі адсорбиії ТЦ відбувається часткове перетворення зміманих оксидів в шаруваті подвійні гідроксиди (ШПГ) з інтеркалящією ТЦ в міжплощинний простір ШПГ. Під час адсорбиї ТЦ змішаними оксидами відбувається їх розчинення, зумовлене утворенням комплексів. Виявлено, щзо в розчині ТЦ після контакту зі змішаними оксидами і ШПГ утворюються комплекси

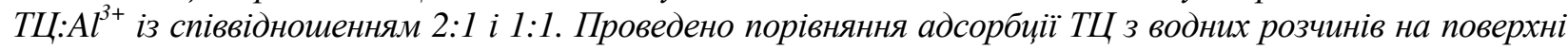
зміманих оксидів i Zn-Al ШПГ, отриманих методом співосадження Показано, щуо Zn-Al змімані оксиди мають вищу сорбиійну ємність в порівнянні з Zn-Al ШПГ. Експериментальні результати оброблені із залученням математичних моделей для рівноважної сорбиії на поверхні твердих тіл.

Ключові слова: шаруваті подвійні гідроксиди, Zn-Al змішані оксиди, реконструкція, адсорбція, тетрачиклін, комплексоутворення

\section{Адсорбция тетрациклина $\mathrm{Zn-Al} \mathrm{смешанными} \mathrm{оксидами} \mathrm{и}$ слоистыми двойными гидроксидами}

\section{Г.Н. Старух}

Институт химии поверхности им. А.А. Чуйко Национальной академии наук Украинь ул. Генерала Наумова, 17, Киев, 03164, Украина, starukh_galina@ukr.net

Изучена адсорбиия ТЦ из водных растворов на поверхности Zn-Al смешанных оксидов. Обнаружено, что в процессе адсорбиии ТЦ происходит частичное преобразование смешанных оксидов в слоистые двойные гидроксиды (СДГ) с интеркалированием ТЦ в межплоскостное пространство СДГ. Во время адсорбции ТЦ смешанными оксидами происходит их растворение, обусловленное образованитем комплексов. Обнаружено, что в растворе ТЦ после контакта со смешанными оксидами и СДГ образуются комплексы ТЦ:А $l^{3+}$ с соотнотением 2:1 и 1:1. Проведено сравнение адсорбиии ТЦ из водных растворов на поверхности смешанных оксидов и Zn-Al слоистых двойных гидроксидов, полученых методом соосаждения. Показано, что $\mathrm{Zn}$-Al смешанные оксиды имеют более высокую сорбиионную емкость по сравнению с Zn-Al СДГ. Экспериментальные результаты обработаны с привлечением математических моделей для равновесной сорбции на поверхности твердых тел.

Ключевые слова: слоистые двойные гидроксиды, Zn-Al смешанные оксиды, реконструкция, адсорбиия, тетрациклин, комплексообразование 


\section{REFERENCES}

1. Gonzalez-Pleiter M., Gonzalo S., RodeaPalomares I. et al. Toxicity of five antibiotics and their mixtures towards photosynthetic aquatic organisms: Implications for environmental risk assessment. Water Res., 47 (2013) 2050. doi.org/10.1016/j.watres.2013.01.020.

2. Jeong J., Song W., Cooper W. et al. Degradation of tetracycline antibiotics: mechanisms and kinetic studies for advanced oxidation/reduction processes. Chemosphere, 78 (2010) 533.

3. Le-Minh N., Khan S.J., Drewes J.E. et al. Fate of antibiotics during municipal water recycling treatment processes. Water Res., 44 (2010) 4295.

4. Goh, K., Lim T., Gong Z. Application of layered double hydroxides for removal of oxyanions: A review. Water Res., 42 (2008) 1343.

5. Cavani F., Trifirò F., Vaccari A. Hydrotalcitetype anionic clays: Preparation, properties and applications. Catal. Today, 11 (1991) 173.

6. Greenwell H., Holliman P, Jones W., Velasco B. Studies of the effects of synthetic procedure on base catalysis using hydroxide-intercalated layer double hydroxides. Catal. Today, 114 (2006) 397. doi: 10.1016/j.cattod.2006.02.035.

7. Carja G., Obata H., Kameshima Y., Okada K. The textural properties of iron substituted hydrotalcites obtained in a tailored aqueousorganic synthesis medium. Micropor. Mesopor. Mater., 98 (2007) 150. doi: 10.1016/j.micromeso.2006.08.026.

8. Turco M., Bagnasco G., Costantino U. et al. Production of hydrogen from oxidative steam reforming of methanol: I. Preparation and characterization of $\mathrm{Cu} / \mathrm{ZnO} / \mathrm{Al}_{2} \mathrm{O}_{3}$ catalysts from a hydrotalcite-like LDH precursor. J. Catal., 228 (2004) 43.

9. Das N., Samal A. Synthesis, characterisation and rehydration behaviour of titanium(IV) containing hydrotalcite like compounds. Micropor. Mesopor. Mater., 72 (2004) 219.

10. Li F., Wang Y., Yang Q. et al. Study on adsorption of glyphosate (N-phosphonomethyl glycine) pesticide on MgAl-layered double hydroxides in aqueous solution. J. Hazard. Mater., 125 (2005) 89.

11. Inacio, J., Taviot-Gueho C., Forano C., Besse J. Adsorption of MCPA pesticide by MgAl- layered double hydroxides. Appl. Clay Sci., 18 (2001) 255.

12. Reis M., Silverio F., Tronto J., Valim J. Effects of $\mathrm{pH}$, temperature, and ionic strength on adsorption of sodium dodecylbenzenesulfonate into $\mathrm{Mg}-\mathrm{Al}-\mathrm{CO}_{3}$ layered double hydroxides. J. Phys. Chem. Solids, 58 (2004) 487.

13. Pavlovic I., Barriga C., Hermosin M. et al. Adsorption of acidic pesticides 2,4D,Clopyralid and Picloram on calcined hydrotalcite. Appl. Clay Sci., 30 (2005) 125.

14. Cardoso L., Valim J. Study of acids herbicides removal by calcined $\mathrm{Mg}-\mathrm{Al}-\mathrm{CO}_{3}-\mathrm{LDH}$. J. Phys. Chem. Solids, 67 (2006) 987.

15. Brei V., Melezhyk O., Starukh G. et al. Organic precursor synthesis of $\mathrm{Al}-\mathrm{Mg}$ mixed oxides and hydrotalcites. Micropor. Mesopor. Mater., 113 (2008) 411. doi: 10.1016/j.micromeso.2007.11.040.

16. Lippens B., Steggerda J. Structure and Properties of Adsorbents and Catalysts, Mir, Moscow, 1973, 190 p. (in Russian).

17. Takehira K., Kawabata T., Shishido T. et al. Mechanism of reconstitution of hydrotalcite leading to eggshell-type $\mathrm{Ni}$ loading on $\mathrm{Mg}-\mathrm{Al}$ mixed oxide. J. Catal., 231 (2005) 92.

18. Costantino U., Ambrogi V., Nocchetti M., Perioli L. Hydrotalcite-like compounds: versatile layered hosts of molecular anions with biological activity. Micropor. Mesopor. Mater., 107 (2008) 149.

doi: 10.1016/j.micromeso.2007.02.005.

19. Xu Z., Fan J., Zheng S. et al. On the adsorption of tetracycline by calcined magnesiumaluminum hydrotalcites J. Environ. Qual., 38 (2009) 1302. doi:10.2134/jeq2008.0246.

20. Gregg S., Sing K. Adsorption, Surface Area and Porosity, Academic Press, London; New York, 1982, $313 \mathrm{p}$.

21. Abelló S., Medina F., Tichit D. et al. Aldol condensations over reconstructed $\mathrm{Mg}-\mathrm{Al}$ hydrotalcites: structure-activity relationships related to the rehydration method. Chem. Eur. J., 11 (2005) 728. doi: 10.1002/chem.200400409.

22. Linares $C$., Brikgi $M$. Interaction between antimicrobial drugs and antacid based on cancrinite-type zeolite. Micropor. Mesopor. Mater., 96 (2006) 141. doi: 10.1016/j.micromeso.2006.05.038.

23. Tavares M., McGuffin V. Separation and characterization of tetracycline antibiotics by 
capillary electrophoresis. J. Chromatogr. A., 686 (1994) 129.

24. Figueroa R., Leonard A., Mackay A. Modeling tetracycline antibiotic sorption to clays. Environ. Sci. Technol., 38 (2004) 476. doi:10.1021/es0342087

25. Nelson M., Hillen W. Tetracyclines in Biology, Chemistry and Medicine, Greenwald Birkhauser Verlag, Basel -Boston-Berlin 2001, $337 \mathrm{p}$.

26. Schneider S., Schmitt M., Brehm G. et al. Fluorescence kinetics of aqueous solutions of tetracycline and its complexes with $\mathrm{Mg}^{2+}$ and $\mathrm{Ca}^{2+}$. Photochem. Photobiol. Sci., 2 (2003) 1107.

27. Sultan S., Alzamil Z., Alarfaj N. Complexometric assay of tetracyclines in drug formulations. Talanta, 35 (1988) 375.

28. Carlotti B., Cesaretti A., Elisei F. Complexes of tetracyclines with divalent metal cations investigated by stationary and femtosecondpulsed techniques. Phys. Chem. Chem. Phys., 14 (2012) 823. doi:10.1039/c1cp22703c.

29. Schmitt M., Schneider S. Spectroscopic investigation of complexation between various tetracyclines and $\mathrm{Mg}^{2+}$ or $\mathrm{Ca}^{2+}$. Phys. Chem. Comm., 3 (2000) 42.

30. $G u \quad C$., Karthikeyan $K$. Interaction of tetracycline with aluminum and iron hydrous oxides. Environ. Sci. Technol., 39 (2005) 2660. doi: 10.1021/es048603o.

31. Omar H., Moloukhia H. Use of activated carbon in removal of some radioisotopes from their waste solutions. J. Hazard. Mater., 157, (2008) 242.

32. Liu M., Hou L., Yu Sh. et al. MCM-41 impregnated with a zeolite precursor: Synthesis, characterization and tetracycline antibiotics removal from aqueous solution. Chem. Eng. J., 223 (2013) 678. doi.org/10.1016/j.cej.2013.02.088

33. Tripathy S., Raichur A. Abatement of fluoride from water using manganese dioxide-coated activated alumina. J. Hazard. Mater., 153 (2008) 1043.

34. Crepaldi E., Tronto J., Cardoso L., Valim J. Sorption of terephthalate anions by calcined and uncalcined hydrotalcite-like compounds. Colloids Surf. A: Physicochem. Eng. Aspects, 211 (2002) 103.

Received 30.07.2014, accepted 23.04.2015 